\title{
Book Piracy Behavior among College Students in Indonesia
}

\author{
Rahma FITRIASIH, Sri Rahayu Hijrah HATI and Adrian ACHYAR
}

Management Department, Faculty of Economics Universitas Indonesia-Depok, Indonesia

Correspondence should be addressed to: Sri Rahayu Hijrah HATI; sri.rahayu72@ui.ac.id

Received date:2 May 2019; Accepted date: 17 July 2019; Published date: 3 September 2019

Academic Editor: Manique Cooray

Copyright (C) 2019. Rahma FITRIASIH, Sri Rahayu Hijrah HATI and Adrian ACHYAR. Distributed under Creative Commons CC-BY 4.0

\begin{abstract}
Piracy, or the counterfeiting of a product, remains an important global issue. This research aims to examine the factors that influence university students' intention in the piracy of academic books. The research conducted is based on previous attitudes toward piracy behavior, subjective norms, and perceived behavioral control. Piracy is both unethical and illegal, and this study develops the theory of planned behavior (TPB) by adding ethics theory addressing moral obligation and perceived benefits and deterrence theory dealing with fear of legal consequences and perceived likelihood of punishment. The research method used in this research is the purposive random sampling technique; online questionnaires are distributed using Google Forms. A total of 293 college students complete the questionnaires. The results of the study show that affect, moral obligation, and perceived benefits have a significant effect on attitude toward pirating academic books. Attitude, habitual conduct, and moral obligation also have a significant effect on intention to pirate. In contrast, fear of legal consequences and perceived likelihood of punishment have no significant effect on attitude toward piracy of academic books. The results of this study can serve as input for the book publishing industry, copyright holders, and the government in efforts to cooperate with other countries to overcome the academic book piracy that has occurred in Indonesia.
\end{abstract}

Keywords: theory of planned behavior; ethics theory; deterrence theory; piracy

\section{Introduction}

Piracy, or the counterfeiting of a product, remains an important global issue. Due to the increasingly widespread production and sale of pirated products, piracy has become a serious threat to the welfare of the world economy. The greatest risk exists for people who cannot distinguish between the counterfeit product and the original. The increasing number of pirated products in international trade has affected the whole world and this problem is growing because of a shift in thinking; the piracy of products

Cite this Article as: Rahma FITRIASIH, Sri Rahayu Hijrah HATI and Adrian ACHYAR (2019)," Book Piracy Behavior among College Students in Indonesia ", Journal of e-Learning and Higher Education, Vol. 2019 (2019), Article ID 253359, DOI: 10.5171/2019.253359 
is no longer aimed exclusively at luxury goods but now includes goods regarded as everyday necessities (Quoquab, Pahlevan, Mohammad, \& Thurasamy, 2017). Piracy is considered a criminal behavior that results in imprisonment, based on existing rules across the world. However, although piracy occurs in almost all countries, it is not easy to stop because even though it is regarded as theft (illegal taking), it is not generally punishable as a crime (Balestrino, 2008).

Academically, studies related to piracy behavior based on the theory of planned behavior (TPB) can be used to explain the intention to engage in piracy (Cronan \& AlRafee, 2008; Phau, Lim, Liang, \& Lwin, 2014; Yoon, 2011). The development of TPB itself has undergone many modifications to explain piracy behavior in detail. Yoon (2011) and Arli and Tjiptono (2016) developed a research model by adding legal consequences based on deterrence theory and ethics related to piracy behavior based on ethics theory. Maldonado and Hume (2005) examined whether individuals who had high ethical values also had a lower evaluation of pirated products. In addition, individuals who had a higher rating on pirated products also had a stronger intention to buy pirated products. Consumer ethics and culture can be seen as a major driving factor that can affect a person's unethical behavior, such as software piracy and music piracy. Also, the influence on attitude toward behaviors in TPB has previously been investigated (Phau et al., 2014).

Usually piracy occurs in countries with low individual incomes and high unemployment rates (Arli \& Tjiptono, 2016). In Indonesia, the number of consumers using pirated products is very large and pirated products often serve as substitutions for the highpriced original. Although criminal acts, product piracy and illegal product downloads occur worldwide, especially among teens and students (Arli \& Tjiptono, 2016). The purpose of this research is to identify the factors that influence the intention to purchase pirated academic books among students based on the development of TPB, ethics theory, and deterrence theory with the addition of effect on attitude toward pirating behavior.

\section{Literature Review}

\section{Theory of Planned Behavior}

\section{Attitude toward Behavior}

Attitude arises out of belief in the consequences of behavior. Many studies have shown that attitude is the most important factor influencing behavioral intention (Ajzen, 2005). Cronan and AlRafee (2008), Phau et al. (2014), Alleyne, Soleyn, and Harris (2015), and Arli and Tjiptono (2016) have shown that attitude toward the behavior influenced the intention surrounding digital product piracy. Because a person's attitude can be influenced and changed by several factors, attitude is an important variable to study.

Affect, as one of the factors that can influence one's attitude, positively or negatively, becomes its own construct in the behavior of someone who directly and significantly influences one's attitude. According to Triandis (1980), affect reflects feelings of happiness, depression, anger, hate, and being upset about certain behavior. Based on previous research stating that affect can influence a person's intentions with respect to digital piracy, a person may not want to get involved in piracy because he or she feels it is not the right action (Loch \& Conger, 1996). Thus, we can hypothesize as follows:

H1: Affect positively influences attitude toward behavior to pirate academic books.

H2: Attitude toward behavior positively influences intention to pirate academic books.

\section{Subjective Norms}

Subjective norms are norms, values, and rules a society adopts; thus, they can affect one's intention to engage in software piracy through considering piracy to be unethical behavior (Loch \& Conger, 1996). Based on Phau et al. (2014), the influence of the environment can motivate individuals to engage in piracy, so social factors have a positive effect on the intention to conduct piracy. Therefore, the following hypothesis is offered: 
H3: Social factors positively influence the intention to pirate academic books.

\section{Perceived behavioral Control}

Based on TPB, perceived behavioral control $(\mathrm{PBC})$ is defined as a person's perception of the complexity of the desired behavior, based on the belief in the availability of resources and the opportunities required to behave in a certain manner (Ajzen, 1991).

\section{Self-Efficacy}

Self-control theory is associated with PBC; for example, Gottfredson and Hirschi (1990) examined the degree of self-control as a decisive factor in all crime. Self-efficacy theory assesses how well a person can perform a behavior; with several factors that reinforce one's behavior, this can affect one's actual behavior (Kuo \& Hsu, 2001). Self-efficacy reflects a belief in one's ability to act on one's needs so that one's desires are achieved (Bandura, 1998). Self-efficacy is also regarded as PBC (Bandura, 1982; Yoon, 2011). Zhang, Smith, and McDowell (2009) suggested that self-efficacy relates to a person's ability to engage in film piracy. Similarly, Krueger and Dickson (1994) found that increased self-efficacy causes a person to feel safe so that the person dares to take high risks. Thus, individuals with high self-efficacy are more likely to engage in behavior that involves danger (e.g., hijacking a movie). Based on these views, the following hypothesis is formulated:

H4: Self-efficacy positively affects the intention to pirate academic books.

\section{Facilitating Conditions}

Facilitating conditions refer to a person's environmental factors that make it easier or more difficult to perform an action. Examples of facilitating conditions in the behavior of piracy include high speed Internet connection, easily accessible pirated digital content and low social awareness of piracy behavior, absence of penalty sanctions, and the ease of obtaining pirated products (Banerjee, Cronan, \& Jones, 1998; Harrington, 1996; Higgins, Fell, \& Wilson, 2006; Pierce \& Henry, 1996). Thus, the ease of committing piracy and the low risk of being caught mean that facilitating conditions are a major factor affecting someone involved in piracy (Cheng, Sims, \& Teegen, 1997). Thus, the following hypothesis is formulated:

H5: Facilitating conditions positively influence the intention to pirate academic books.

\section{Habitual Conduct}

Habitual conduct is associated with sequential behavior that is automatic and occurs without the need for instruction (Triandis, 1980). Habitual conduct comes from a person's past based on that person's ability to complete a particular job; thus, habitual conduct is part of an individual's PBC to engage in piracy behavior (Phau et al., 2014). Hunt and Vitell (1986) suggested that a person's experience in the past has an effect on ethical behavior. According to Limayem et al. (2004) and Yoon (2011), past behavior may influence the intention to engage in certain behaviors.

H6: Habitual conduct positively influences the intention to pirate academic books.

\section{Ethics theory}

Hunt and Vitell (1986) classified ethics theory into two groups: deontological theory and teleological theory. In research on digital piracy behavior, two variables that can represent ethics theory are moral obligation (deontological theory) and perceived benefits (teleological theory) (Yoon, 2011).

\section{Moral Obligation}

Ajzen (1991) found that moral obligation can affect intentions in terms of unethical behavior and can be added to the TPB as a factor that can influence a person's attitude. Because piracy is an illegal act, the person who buys pirated products or engages in digital piracy will confront a dilemma because the unethical nature of piracy can affect the decision-making process (Chiou, Huang, \& Lee, 2005). The higher the level of moral judgment or guilt that a person feels toward digital piracy behavior, or the lower 
the commitment to engage in digital piracy, the more negative the attitude toward digital piracy and the less desire to engage in the behavior (Cronan \& Al-Rafee, 2008). Based on previous research, moral obligation negatively affects attitude toward the behavior of digital product piracy (Arli \& Tjiptono, 2016; Cronan \& Al-Rafee, 2008; Yoon, 2011) and intention to engage in piracy (Alleyne et al., 2015; Cronan \& AlRafee, 2008; Yoon, 2011). With these considerations one can hypothesize as follows:

H7: Moral obligation negatively influences the attitude toward the pirating of academic books.

H8: Moral obligation negatively influences the intention to pirate academic books.

\section{Perceived Benefits}

Piracy behavior has both negative and positive consequences (Goles et al., 2008; Yoon, 2011). Attitudes toward piracy behavior are a function of the belief that behavior will lead to certain results (Ajzen \& Fishbein, 1977). Perceived benefits (e.g., convenience, time and money savings) significantly influence the propensity for piracy (Hunt \& Vitell, 1986; Yoon, 2011). For example, Yoon (2011) found that perceived benefits positively influence both attitudes toward digital piracy and intention to pirate digital products. Thus, we can formulate the following hypothesis:

H9: Perceived benefits positively influence the attitude toward pirating academic books.

\section{Deterrence Theory}

People will likely avoid committing a crime if they believe they will receive a severe punishment for doing so. Deterrence theory is associated with the notion that a person is prevented from performing an illegal act due to the threat of punishment. Ehrlich (1996) argued that this theory can be directly linked to economic factors and showed that many crimes of copyright infringement occur due to the profits resulting from the crime. This theory has been adapted to several studies of piracy, using the two main factors of fear of legal consequences and perceived likelihood of punishment (Moores, Nill, \& Rothenberger, 2009). Deterrence theory shows that individuals are actors who can think rationally in choosing to engage or not in unlawful behavior (Gunter, 2009). In the context of TPB, the fear of legal consequences and the perceived likelihood of punishment form an attitude toward book and ebook piracy (Arli \& Tjiptono, 2016). Similarly, according to Tan (2002), these two factors greatly affect consumer attitudes toward digital piracy. Based on the above description, the following hypotheses are formulated:

H10: Fear of legal consequences negatively influences the attitude toward buying pirated books or downloading e-books illegally.

H11: Perceived likelihood of punishment negatively influences the attitude toward buying pirated books or downloading e-books illegally. 


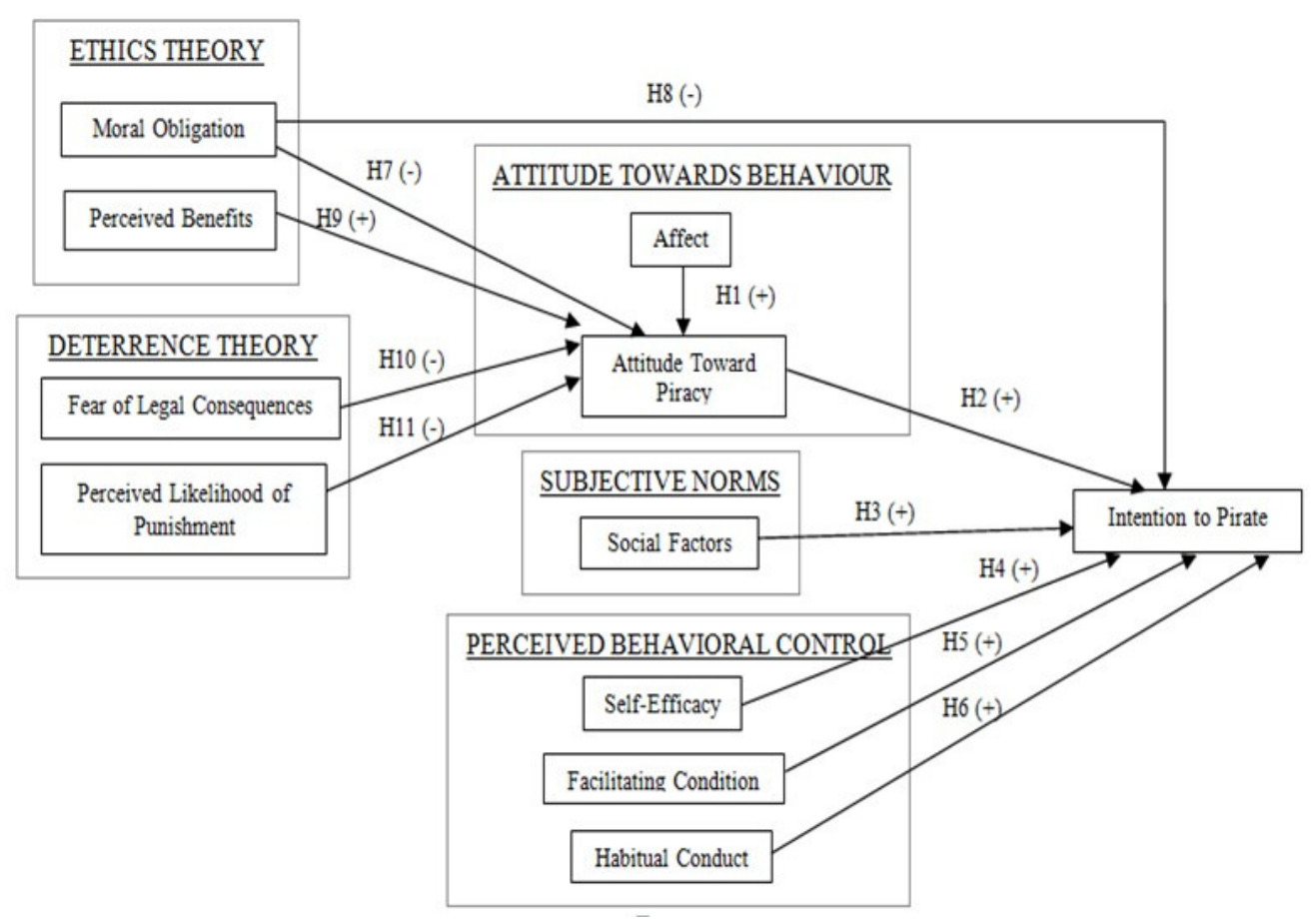

Figure 1: Research model

\section{Research Method}

\section{Sample and data collection}

This research used a quantitative method. According to Hair, Black, Babin, Anderson, and Tatham (2010), a quantitative research method prioritizes measurement and sampling due to using a deductive mind-set with more detail in the data set and the results of analysis. The samples chosen in this study are based on criteria that have been determined by the researchers so that the information obtained is in accordance with the purpose of research (Sekaran \& Bougie, 2013). This study uses a nonprobability sampling technique in which the selected respondents do not have the opportunity to be re-elected for use as research samples. The sample selected in this study are university students. Students are selected as the sample because students are accustomed to using pirated products (Phau \& Liang, 2012; Yoon, 2011). This claim has been demonstrated by the number of studies conducted to explain the driving factors in piracy behavior as viewed from various aspects, using student samples as respondents (Arli \& Tjiptono, 2016; Phau \& Liang, 2012).

\section{Measurement}

To obtain information from respondents, questionnaires were administered. A questionnaire is a series of questions or statements arranged in such a way as to obtain appropriate information (Zikmund et al., 2010). The questionnaire used in this study was adapted from previous research questionnaires that had been tested for validity and reliability. The respondents replied to 46 indicator statements using a 7point Likert scale, 1 being "strongly disagree" and 7 being "strongly agree."

Before the questionnaire was disseminated, the researchers conducted a pilot test with 30 student respondents to determine whether respondents easily understood the questionnaire items and whether the results were consistent with the research objectives. Data processing employed structural equation modeling (SEM) using the LISREL program.

\section{Analysis and Discussion}

The data come from 293 students who are still active in college. The demographic profile of respondents in this study is as 
follows: 172 female respondents (59\%) and 121 male respondents (41\%). Most of the respondents were aged $17-25$ years (73\%), with the educational background of high school by $45 \%$ and bachelor's degree by 41\%. For more details, see Table 1.

Table 1: Demographics of respondents

\begin{tabular}{|l|c|c|}
\hline \multicolumn{1}{|c|}{ Item } & Frequency & $\begin{array}{c}\text { Percentage } \\
\text { (\%) }\end{array}$ \\
\hline Gender & & \\
\hline Male & 121 & 41 \\
\hline Female & 172 & 59 \\
\hline Age & 215 & 73 \\
\hline 17 - 25 years & 59 & 20 \\
\hline 26 - 34 years & 18 & 6 \\
\hline 35 - 43 years & 1 & 1 \\
\hline$>44$ years & 133 & 45 \\
\hline Education Level & 15 & 5 \\
\hline High School & 119 & 41 \\
\hline Diploma & 26 & 9 \\
\hline Bachelor & & 100 \\
\hline Master & & \\
\hline Total & & \\
\hline
\end{tabular}

Structural testing included a bootstrapping method to test statistical calculations using LISREL 8.5 to process data of 293 respondents. In this research, data processing was based on a measurement model (outer model) and a structural model (inner model). Testing validity (convergent and discriminant validity) and reliability testing (composite reliability) were part of the measurement model. Furthermore, the results of the goodness-of-fit index (GOFI) value of the measurement model were based on the research model, as shown in Table 2 .

Table 2: Goodness-of-fit index measurement model

\begin{tabular}{|l|c|c|c|}
\hline \multicolumn{1}{|c|}{ GOFI } & Output Model & Control of Value & Result \\
\hline RMSEA & 0.056 & RMSEA $\leq 0.08$ & Good Fit \\
\hline NFI & 0.89 & NFI $\geq 0.90$ & Marginal Fit \\
\hline NNFI & 0.93 & NNFI $\geq 0.90$ & Good Fit \\
\hline CFI & 0.94 & CFI $\geq 0.90$ & Good Fit \\
\hline IFI & 0.94 & IFI $\geq 0.90$ & Good Fit \\
\hline SRMR & 0.057 & $0.05 \leq S R M R \leq 0.08$ & Good Fit \\
\hline GFI & 0.79 & GFI $\geq 0.90$ & Poor fit \\
\hline
\end{tabular}


Table 2 shows that almost all goodness-offit results show a good fit; thus, the overall measurement model fits and can be used in testing the next model parameters.

\section{Hypotheses based on the research model (Figure 1)}

Bootstrapping results were better even though the number of samples was small. The study was a two-tailed test with a critical value at a significance level of $10 \%$ (1.65), 5\% (1.96), or 1\% (2.58) (Hair et al., 2011). If the t-value is greater than its significance level, the relationship between variables is significant. Based on the test results, the coefficient of determination $\left(\mathrm{R}^{2}\right)$ from affect, moral obligation, perceived benefits, fear of legal consequences, and perceived likelihood of punishment explain $56 \%$ of the attitude toward the behavior of piracy, while attitude toward behavior, moral obligation, social factors, self-efficacy, facilitating condition, and habitual conduct explain $68 \%$ of intention to pirate.

H1 test results show that affect positively and significantly influences attitude toward behavior in purchasing a pirated book or downloading an e-book illegally (academic book) $(\mathrm{t}=8,81$; sig $=5 \%)$, and $\mathrm{H} 2$ shows that attitude toward behavior significantly and positively influences against the intention to buy pirated books or download e-books illegally $(\mathrm{t}=1.89$; $\mathrm{sig}=10 \%)$. H3 suggests that social factors have a positive effect on the intention to buy a pirated book or hijack an e-book. Different from the hypothesis, the results are not significant where the $\mathrm{t}$-value $<\mathrm{t}$ table $(0.08<1.96)$. The results for $\mathrm{H} 4$ are also insignificant, suggesting that self-efficacy has no positive effect on the intention to buy pirated books or download e-books illegally. With regard to $\mathrm{H} 5$, facilitating condition has no significant positive effect on the intention to buy pirated books or download e-books illegally. H6 indicates that habitual conduct positively affects the intention to buy pirated books or download e-books illegally. The test results show a significant positive relationship $(t=11.74, \quad$ sig $=5 \%)$. For $H 7$, moral obligation negatively affects attitude toward the behavior of purchasing pirated books or downloading e-books illegally and H8 anticipates that moral obligation negatively affects the intention to pirate, the purchasing of pirated books, and the illegal downloading of e-books. The results also show a negative and significant relationship $(\mathrm{H} 7 \rightarrow \mathrm{t}=-1.69 ; \mathrm{sig}=10 \% ; \mathrm{H} 8 \rightarrow \mathrm{t}=-1.80$; sig $=10 \%$ ). H9 predicts that perceived benefits positively affect the attitude toward the behavior of purchasing pirated books or downloading e-books illegally. $\mathrm{H} 10$ is not significantly different from the hypothesis, where fear of legal consequences negatively affects attitude (attitude toward behavior) in purchasing a pirated book or a hijacked ebook. Similarly, H11 results are also not significant with respect to the perceived likelihood of punishment negatively affecting attitude (attitude toward behavior) to buy pirated books or download e-books illegally. Table 4 shows the results of hypothesis testing.

Table 4: Summary of hypothesis testing results

\begin{tabular}{|c|l|c|c|l|}
\hline Hypothesis & \multicolumn{1}{|c|}{ Path } & SLF & \multicolumn{1}{|c|}{$t$} & \multicolumn{1}{|c|}{ Result } \\
\hline H1 (+) & Affect $\rightarrow$ Attitude Toward & 0.56 & $8.81^{*}$ & Supported \\
\hline H2 (+) & Attitude $\rightarrow$ Intention to Pirate & 0.087 & $1.89^{* *}$ & Supported \\
\hline H3 (+) & Social Factor $\rightarrow$ Intention to Pirate & 0.004 & 0.08 & Not supported \\
\hline H4 (+) & Self-Efficacy $\rightarrow$ Intention to Pirate & - & 0.50 & Not supported \\
\hline H5 (+) & Facilitating Condition $\rightarrow$ Intention to Pirate & 0.022 & & \\
\hline H6 (+) & Habitual Conduct $\rightarrow$ Intention to Pirate & 0.002 & 0.06 & Not supported \\
\hline H7 (-) & Moral Obligation $\rightarrow$ Attitude Toward & - & $-1.69^{* *}$ & Supported \\
\hline H8 (-) & Moral Obligation $\rightarrow$ Intention to Pirate & -0.08 & $-1.80^{* *}$ & Supported \\
\hline H9 (+) & Perceived Benefit $\rightarrow$ Attitude Toward & 0.19 & $3.58^{*}$ & Supported \\
\hline
\end{tabular}




\begin{tabular}{|c|l|c|c|c|}
\hline H10 (-) & Fear of Legal Consequences $\rightarrow$ Attitude Toward & - & -0.89 & Not supported \\
\hline H11 (-) & Perceived Likelihood of Punishment $\rightarrow$ Attitude Toward & - & -0.24 & Not supported \\
\hline
\end{tabular}

Notes: ${ }^{*}$ t-value $>1.96(\operatorname{sig}=5 \%) ;{ }^{* *}$ t-value $>1.645(\operatorname{sig}=10 \%)$

\section{Discussion and Conclusion}

Piracy is a serious problem that may never end, and it can occur in both developing and developed countries. The problem of piracy has grown with a shift in thinking; product piracy is no longer aimed exclusively at luxury goods but now also includes goods used for daily necessities (Quoquab et al., 2017). The results show that affect significantly and positively influences students' attitude toward piracy. The results imply that the lack of a strict rule of law and the lack of a person's ethical cultivation of piracy behavior have given Indonesian students a positive attitude toward buying pirated products without any feeling that the action can harm many.

The results also show that attitude has a significant influence on the intention to pirate products. In other words, respondents' positive attitude toward academic book piracy strongly supports their intention to pirate academic books. The results are consistent with research conducted by Alleyne et al. (2015), Arli and Tjiptono (2016), Cronan and Al-Rafee (2008), and Phau et al. (2014), indicating that attitude toward behavior has a strong influence on the intention to pirate products.

People can be motivated to perform certain behaviors if they receive feedback, suggestions, or comments from others who agree with the behaviors. Motivation that comes from others is a social factor of behavior. Social factors come from family, friends, and the environment, where the values, norms, and rules can influence a person's intentions to engage in piracy behavior. The results of this study contradict the results obtained by Limayem et al. (2004) and Phau et al. (2014), who reported that social factors have a positive effect on the intention to pirate. However, Arli and Tjiptono (2016), Moores et al. (2009), and Setiawan and Tjiptono (2013) supported the results of this study, where subjective norms do not affect one's intention in piracy. This is because while individuals may be aware that piracy violates the law, because their surrounding community is accustomed to piracy behavior, violating the law has no effect on the intention to pirate.

This study shows that self-efficacy has a positive effect on intention in piracy behavior. Self-efficacy indicates that a person is convinced that he or she is able to perform piracy behavior based on need. Krueger and Dickson (1994) argued that increased self-efficacy causes a person to feel safer in taking a high risk; so individuals with high self-efficacy are more likely to engage in dangerous behavior (e.g., film piracy). However, this differs from the results obtained. Self-efficacy does not affect the intention to engage in piracy because the individual who feels high self-control does not want to engage in piracy behavior. Individuals are aware that piracy is a risk because it carries penal sanctions. These results are similar to those of Gottfredson and Hirschi (1990), Moores et al. (2009), and Setiawan and Tjiptono (2013), who associated self-control theory with PBC. Such self-control demonstrates the selfefficacy assessment by seeing how well a person can take action on the basis of the encouraging factors in piracy.

Environmental factors can make it easier or more difficult for a person to act. The rise of piracy in Indonesia indicates that the availability of resources and opportunities in piracy are very high. In this study, facilitating condition has no effect on intention to engage in piracy. This finding is confirmed in studies conducted by Phau et al. (2014). Limayem et al. (2004) stated that facilitating conditions significantly affect actual software piracy behavior. According to Triandis (1980), this difference can occur because facilitating conditions affect the actual behavior rather than the intention; that is, the possibility of someone having an intention to engage in piracy behavior will not necessarily be followed by actual behavior if the environment does not support the person in that behavior.

Indonesian people are accustomed to piracy. A person accustomed to buying 
pirated products will usually continue to do so in the future. The results of this study indicate that habitual conduct positively affects behavior. Similarly, Limayem et al. (2004) and Yoon (2011) explained that past behavior may influence the future intention to engage in certain behaviors.

Consumer ethics is the main driver of consumer misbehavior, including the action of piracy. This study shows that the attitude toward behavior mediates the relationship between consumers' moral obligation and perceived benefits, and the attitude affects the intention to pirate academic books. Moral obligation has a significantly negative effect, while perceived benefits and affects have a positive effect. Yoon (2011) explained that someone who has high morals will avoid piracy because that person will realize that the act is wrong and breaks the law. The higher the level of moral judgment or guilt that a person feels toward digital piracy behavior, the more negative the effect of attitudes toward digital piracy and the less desire to take action (Cronan \& Al-Rafee, 2008).

Attitudes toward piracy behavior develop because consumers have confidence that piracy will achieve certain results (Ajzen \& Fishbein, 1977). Yoon (2011) stated that fewer sacrifices (convenience, low prices, and easy to obtain) are the benefits gained in piracy behavior. Perceived benefits are significantly influential in committing acts of piracy. The higher the perceived benefits of piracy, the greater the desire to perform piracy (Goles et al., 2008).

Deterrence theory in this study relies on two variables: fear of legal consequences and perceived likelihood of punishment. The results of statistical tests of these two variables indicate that the variable does not have a significant effect on the intention to engage in academic books piracy. The results are supported by Arli and Tjiptono's (2016) research suggesting that Indonesian consumers are not afraid of the legal consequences of copyright infringement via piracy. It is likely that most Indonesians think that selling pirated products is illegal, but such lawlessness does not apply when they buy pirated products. Weak law enforcement in Indonesia has long been the focus of the International Intellectual Property Alliance (IIPA). This indicates a lack of oversight and dissemination of the importance of legal awareness of the copyright protected by the government. Therefore, deterrence theory is less effective for use in piracy research in Indonesia (Arli \& Tjiptono, 2016). Indonesian people are accustomed to piracy. A person accustomed to buying pirated products will usually continue to do so in the future. The results of this study indicate that habitual conduct has a positive effect. Similarly, Limayem et al. (2004) and Yoon (2011) argued that past behavior influences the future intention to engage in certain behaviors. In this study, habitual conduct has the greatest influence on a person's intention to engage in piracy. This is further reinforced by the assumption that piracy is common and committed by many people.

\section{Implications and Future Research Directions}

The results imply that governments, book publishers, and copyright holders should work together to publicize the importance of ethical conduct in the purchase of books and the moral consequences of piracy being against the law. This will be more effective than warning or threatening punishment, as there is still a lack of awareness among Indonesians about copyrights (Arli \& Tjiptono, 2016). In addition, the government under the Ministry of Education can cooperate with publishers and copyright holders to print books at affordable prices for students with limited money and to purchase licenses for college books that students can download free of charge.

Due to more than one value added tax (VAT), such as paper and other raw materials taxes, taxes on book printing, and a final tax on the sale of the book, the price of a book can soar. Therefore, the government can also consider providing subsidies or eliminating such taxes, especially for lecture books.

Although this research has explained some of the contributing factors in piracy behavior, including support factors (e.g., age, income, sex), it still does not fully explain the underlying reasons for a person's behavior. Further research is needed regarding perceptions of the risks that are accepted if one engages in piracy. 
In addition, one's intention to engage in piracy behavior is essentially influenced by driving factors. The literature on TPB has explained that if one already has an intention then that intention will lead to actual behavior (Ajzen, 1991; Venkatesh \& Bala, 2008). Future research can investigate the actual behavior of someone who has the intention to purchase pirated products.

\section{Acknowledgment}

This research was supported financially by a PITTA Grant to Directorate Research and Community Services Universitas Indonesia.

\section{References}

1. Ajzen, I. (1991). The theory of planned behavior. Organizational Behavior and Human Decision Processes. https://doi.org/10.1016/0749-

5978(91)90020-T

2. Ajzen, I. (2005). Attitudes, personality and behavior. Mapping social psychology. https://doi.org/10.1037/e418632008-001 3. Ajzen, I., \& Fishbein, M. (1977). Attitudebehavior relations: A theoretical analysis and review of empirical research. Psychological Bulletin. https://doi.org/10.1037/0033-

2909.84.5.888

4. Alleyne, P., Soleyn, S., \& Harris, T. (2015). Predicting accounting students' intentions to engage in software and music piracy. Journal of Academic Ethics. https://doi.org/10.1007/s10805-0159241-7

5. Arli, D., \& Tjiptono, F. (2016). Consumer digital piracy behaviour among youths: Insights from Indonesia. Asia Pacific Journal of Marketing and Logistics. https://doi.org/10.1108/APJML-11-20150163

6. Balestrino, A. (2008). It is a theft but not a crime. European Journal of Political Economy.

https://doi.org/10.1016/j.ejpoleco.2007.11. 002

7. Bandura, A. (1982). Self-efficacy mechanism in human agency. American Psychologist.

https://doi.org/10.1037/0003-

066X.37.2.122

8. Bandura, A. (1998). Health promotion from the perspective of social cognitive theory. Psychology and Health. https://doi.org/10.1080/08870449808407 422
9. Banerjee, D., Cronan, T. P., \& Jones, T. W. (1998). Modeling IT ethics: A study in situational ethics. MIS Quarterly. https://doi.org/10.2307/249677

10.Cheng, H. K., Sims, R. R., \& Teegen, H. (1997). To purchase or to pirate software: An empirical study. Journal of Management Information Systems. https://doi.org/10.1080/07421222.1997.1 1518142

11.Chiou, J. S., Huang, C. Y., \& Lee, H. H. (2005). The antecedents of music piracy attitudes and intentions. Journal of Business Ethics. https://doi.org/10.1007/s10551004-5263-6

12.Cronan, T. P., \& Al-Rafee, S. (2008). Factors that influence the intention to pirate software and media. Journal of Business Ethics. https://doi.org/10.1007/s10551007-9366-8

13.Ehrlich, I. (1996). Crime, punishment, and the market for offenses. Journal of Economic Perspectives. https://doi.org/10.1257/jep.10.1.43

14.Goles, T., Jayatilaka, B., George, B., Parsons, L., Chambers, V., Taylor, D., \& Brune, R. (2008). Softlifting: Exploring determinants of attitude. Journal of Business Ethics. https://doi.org/10.1007/s10551007-9361-0

15.Gottfredson, M. R., \& Hirschi, T. (1990). A general theory of crime. Stanford University Press.

16.Gunter, W. D. (2009). Internet scallywags: A comparative analysis of multiple forms and measurements of digital piracy. Western Criminology Review.

17.Hair, J. F., Black, W. C., Babin, B. J., Anderson, R. E., \& Tatham, R. L. (2010). Multivariate data analysis. Prentice Hall. https://doi.org/10.1016/j.ijpharm.2011.02. 019

18.Harrington, S. J. (1996). The effect of codes of ethics and personal denial of responsibility on computer abuse judgments and intentions. MISQ. https://doi.org/10.2307/249656

19.Higgins, G. E., Fell, B. D., \& Wilson, A. L. (2006). Digital piracy: Assessing the contributions of an integrated self-control theory and social learning theory using structural equation modeling. Criminal Justice Studies. https://doi.org/10.1080/14786010600615 934

20.Hunt, S. D., \& Vitell, S. (1986). A general theory of marketing ethics. Journal of Macromarketing. 
https://doi.org/10.1177/02761467860060 0103

21.Krueger, N., \& Dickson, P. R. (1994). How believing in ourselves increases risk taking: Perceived self-efficacy and opportunity recognition. Decision Sciences. https://doi.org/10.1111/j.1540-

5915.1994.tb01849.x

22.Kuo, F. Y., \& Hsu, M. H. (2001). Development and validation of ethical computer self-efficacy measure: The case of softlifting. Journal of Business Ethics. https://doi.org/10.1023/A:101071550482 4

23.Limayem, M., Khalifa, M., \& Chin, W. W. (2004). Factors motivating software piracy: A longitudinal study. IEEE Transactions on Engineering Management. https://doi.org/10.1109/TEM.2004.835087 24.Loch, K. D., \& Conger, S. (1996). Evaluating ethical decision making and computer use. Communications of the ACM. 25.Maldonado, C., \& Hume, E. C. (2005). Attitudes toward counterfeit products: An ethical perspective. Journal of Legal, Ethical and Regulatory Issues.

26.Moores, T. T., Nill, A., \& Rothenberger, M. A. (2009). Knowledge of software piracy as an antecedent to reducing pirating behavior. Journal of Computer Information Systems. 27.Phau, I., \& Liang, J. (2012). Downloading digital video games: Predictors, moderators and consequences. Marketing Intelligence and Planning. https://doi.org/10.1108/02634501211273 832

28.Phau, I., Lim, A., Liang, J., \& Lwin, M. (2014). Engaging in digital piracy of movies: A theory of planned behaviour approach. Internet Research. https://doi.org/10.1108/IntR-11-20120243

29.Pierce, M. A., \& Henry, J. W. (1996). Computer ethics: The role of personal, informal, and formal codes. Journal of Business Ethics.

https://doi.org/10.1007/BF00380363

30.Quoquab, F., Pahlevan, S., Mohammad, J., \& Thurasamy, R. (2017). Factors affecting consumers' intention to purchase counterfeit product: Empirical study in the Malaysian market. Asia Pacific Journal of Marketing and Logistics, 29(4), 837-853.

31.Sekaran, \& Bougie. (2013). Research method for business: A skill-building approach. Wiley. https://doi.org/http://as.wiley.com/WileyC DA/WileyTitle/productCd-

111994225X.html\#

32.Setiawan, B., \& Tjiptono, F. (2013). Determinants of consumer intention to pirate digital products. International Journal of Marketing Studies, 5(3), 48.

33.Tan, B. (2002). Understanding consumer ethical decision making with respect to purchase of pirated software. Journal of Consumer Marketing. https://doi.org/10.1108/07363760210420 531

34.Triandis, H. C. (1980). Values, attitudes, and interpersonal behavior. In Nebraska Symposium on Motivation. https://doi.org/10.1016/S0969-

4765(04)00066-9

35.Venkatesh, V., \& Bala, H. (2008). Technology acceptance model 3 and a research agenda on interventions. Decision Sciences. https://doi.org/10.1111/j.15405915.2008.00192.x

36.Yoon, C. (2011). Theory of planned behavior and ethics theory in digital piracy: An integrated model. Journal of Business Ethics. https://doi.org/10.1007/s10551010-0687-7

37.Zhang, L., Smith, W. W., \& McDowell, W. C. (2009). Examining digital piracy. Information Resources Management Journal. https://doi.org/10.4018/irmj.2009010102 38.Zikmund, W. G., Babin, B. J., Editorial, V. P., Calhoun, J. W., Thomas, J., Assistant, E., ... Fuller-Jacobsen, B. (2010). Exploring marketing research. Southwestern Publishing. 